\title{
Redefining our Identities through Social Cohesion: A Poetic Inquiry of Early Career Academics in a Teacher Education Institution
}

\author{
Nosipho Mbatha \\ ORCID iD: https://orcid.org/0000-0002-1989-3940
}

\author{
Vusi Msiza \\ ORCID iD: https://orcid.org/0000-0003-1178-136X
}

\author{
Nokukhanya Ndlovu \\ ORCID iD: https://orcid.org/0000-0002-4280-2998
}

\begin{abstract}
Social cohesion is an important characteristic of a transformative society. Within higher education institutions, academics are tasked with fostering social cohesion by cultivating mutually nourishing connections between diverse histories and positionings. In this paper, we examine how we are navigating the academic space as early career academics (ECAs) who wish to foster a socially cohesive environment. We generated data using a poetic inquiry method that is recognised within the self-reflexive approaches. Our inquiry is guided by the following question: how does social cohesion enable us to redefine our identities in the academic space? Using intersectionality theory, we examine how our critical friendship has aided us in transcending through the 'othering' we were experiencing in the academic space. We also demonstrate how our lived intersectional experiences have assisted us in redefining our personal and professional identities. We found that our critical friendship has aided us in identifying and confronting the 'othering' we were experiencing in the organisational space. Also, we have consciously created
\end{abstract}


our own alternate space where we disempower any form of 'othering' and, through this, we have been able to create a socially cohesive environment that values our intersectional experiences.

Keywords: Early Career Academics, Critical Friendships, Social Cohesion, Othering

Being in an island; being displaced; did not feel like an academic, did not belong; feeling small, felt belittled, marginalized; infantilized; felt belittled for asking; felt othered; othering; constant reference to our inexperience; heightens lack and inabilities; was made to feel like I am not an academic; they did not see me as capable; special case; discrimination; increased anxieties; disturbances; fast paced; silos; Tira moment; rejection, prescribed norms.

\section{Figure 1: The word box}

\section{We almost Sank}

This paper gives an account of how, as early career academics (ECAs), we found ourselves in a place of doubt, with heightened feelings of being an impostor and of being inferior within the academy. Such perspectives on ourselves were created by an environment within our workplace, which we refer to as the dominant space, where we encountered, individually and on various occasions, incidents of marginalization, othering, and rejection. Whether enacted intentionally or not, these incidents led each of us toward a downward trajectory in our academic careers. Seeds of self-doubt and low self-esteem were sown within each of us, and we succumbed to seeing ourselves as incapable, unfit to be in the profession we once believed we were fit for. Disempowered in our offices, we locked ourselves in and allowed the segregating attitude of working in silos to consume us. The word box above is part of the raw data that highlights our emotional state. Such words are used throughout the paper as indicators of our progressions from negativity to collegiality in our alternative space. Through this paper, we share how we managed to bring back our power through collaboration as young ECAs at a school of education. We illustrate how a socially cohesive 
environment created in the alternative space has helped redefine our personal and professional identities. We ask the question: How does social cohesion enable us to redefine our identities in the academic space?

\section{Understanding Social Cohesion for Collegiality}

Social cohesion is a concept that has continuously evolved. There has been an array of understandings, predominantly emphasizing its multidimensionality (Fonseca, Lukosch \& Brazier 2019; Novy, Swiatek \& Moulaert 2012). According to the Organisation for Economic Co-operation and Development, social cohesion is demonstrated when a group works towards the well-being of its members; fosters a sense of belonging and trust; fights exclusion and marginalization; and creates an environment where upward mobility can be achieved by its members (OECD 2011). This multidimensionality is demonstrated above through the multiple characteristics that need to be shown for social cohesion to exist. The central tenet of social cohesion is the emphasis on the quality of meaningful human relationships. These form the basis for social bonds, through which trust, belonging, interdependdence, and shared values are cultivated. They also serve as the glue that holds the group together with a shared mission and goals, communities of interpretation, and legitimate mechanisms to minimize and solve conflict, while promoting tolerance (Berkman \& Kawachi 2000; Capshaw 2005; Durkheim 1897; Fonseca et al. 2019). By its very nature, social cohesion is an ongoing process (Beauvais \& Jenson 2002) that is held to enrich the individual, the institution, or the whole community (Fonseca et al. 2019).

Although various working understandings of social cohesion have been established, the multicultural nature of societies and institutions, coupled with the plurality of subjective values of individuals, presents challenges on how, and what best means are available, to foster social cohesion (Fonseca et al. 2019). Tensions arise in balancing the liberties of diversity and autonomy with sufficiently homogenous understandings, such that mutually nourishing connections between various histories and positioning are cultivated (Novy et al. 2012). Consequently, the means through which this can be achieved is under-theorized (ibid.), which gives us the reason for this paper.

The project of fostering social cohesion is imperative in South Africa and at higher education institutions (HEIs) in particular, given the snail's 
pace of the transformation needed to remedy the historic imbalance of participation and representation (Department of Higher Education and Training 2015). As 'latecomers', Black academics are 'infantilized as perpetual development projects' and still subject to overt and covert exclusion and discrimination (Khunou et al. 2019:2). Unsurprisingly, the findings of the 2008 Soudien report on HEIs conclude that, while many institutions do have progressive transformation policies, these have not translated into institutional cultures with a sense of social cohesion where all members feel valued (Department of Education 2008). We also resonate with the experience expressed by Khunou and the findings emanating from the report. Nevertheless, these experiences happened in a predominantly Black context. We believe it is our intersecting identities that result in these incidents, because 'power structures the ways in which we inhabit the world and influences how we experience belonging and exclusion' (Canham 2019: 113).

As ECAs with no doctoral qualifications, we experience various forms of misrecognition and othering from being treated and made to feel like we are not certified academics (Mbatha et al. 2020). This is further fuelled by the fact that we are not well published (Mahabeer, Nzimande \& Shoba 2018) and are thus treated as dead weight because of our limited ability to generate income for the university through publications (Mbatha et al. 2020). Furthermore, we experience the burden of high teaching workloads, because senior academics are typically unwilling to teach undergraduate modules (Phaswana 2019) and quickly fill their workload with postgraduate supervision, as this has more currency. In meetings, they are heard to utter that such practices are justified because they are the ones who 'carry' the disciplines. After all, they are research productive. Are these the same academics who taunt and patronize us with questions like 'When are you completing your PhD?', 'Have you published?', knowing very well that we are trying to keep afloat because of the high workload and, as such, experience extreme challenges in building our research profiles not only for career progression but also for recognition in the academy (Eley et al. 2012; Moodley et al. 2015). Such practices and treatment intensify the neoliberalindividualistic self-serving agendas in HEIs (Heyneman et al. 2007) and, whether intentional or not, create belligerent attitudes, resulting in disputatious behaviours that work against efforts to foster social cohesion within the academic community.

Consequently, because of our limited research and supervision capi- 
tal, lack of PhDs and age (Mbatha et al. 2020), we are infantilized. This also occurs because, unlike most of our colleagues, we have been appointed at the same institutions where we are completing our doctoral studies. We have also been appointed without having school management experience. From our view, the school of education is dominated by members of staff who, in their previous careers, served in various capacities in school management prior to joining the university. Therefore, the lack of this experience is regarded as some deficiency by some within our context. Emphasis on this threatens the intellectual project that teacher education institutions should engage in (Pinar 2004) and creates workplace divisions.

As female academics, we are marginalized by a patriarchal culture that expects us to be submissive (Mahabeer et al. 2018). The supporters of this culture are not only males, but also Black female academics in positions of authority. This does not mean that the one co-author who is male is immune to subjugation; he recognises that he benefits from patriarchal privilege, but is still subjugated as ECA (Canham 2019). We further experience benevolent sexism disguised as compliments on dress and beauty. Female ECAs are objectified. For instance, one of the female co-authors was told that she was a rose of the discipline and constantly received comments stating that she looked better in dresses than in pants. With reference to this experience, Wright, Thompson and Channer (2007) observe that we interact with sophisticated people in the academy. As a result, 'what you experience is very tacit, unwitting ... sexism; it is a structural system used to exclude you from certain opportunities as opposed to people being blatantly ... sexist' (Canham 2019:151).

All these experiences translate into micro-invalidations; we are labelled as 'izingane za Dean' (the Dean's children) in pervasive narratives we hear through corridor talks (Belluigu \& Thondlana 2018). This labelling suggests that we are 'token' appointments based on our age, race, and gender (Naicker 2013), heightening feelings of being an impostor within the academy. The impostor phenomenon is produced because we are made to feel that our shortcomings are not a function of being ECAs and being a novice (Cisco 2019). Instead, they are expressed as a product of our intellectual inability (ibid.) in an environment that continually recognizes what one cannot do, as opposed to what one does and can do (Mahabeer et al. 2018). For us as ECAs, these experiences undermine the project of social cohesion in the academy. 
Alongside these messages and experiences, we are privileged to have recognition from and interactions with another group of academics who support, mentor and affirm us, partly through reading our abstracts and papers and giving us constructive feedback; partly through engaging with us as colleagues and not just as $\mathrm{PhD}$ students. They are approachable and avail themselves to us to engage with ideas, seek advice and invite us to cosupervise students or write papers with them. These actions are 'intellectually and emotionally affirming' (Canham 2019:13) and suggest that within the academy there are those who invest in our professional development, regardless of the rank we occupy. Our experiences relate to those of Canham (2019), who works at a predominantly white university where race is the first marker of oppression and privilege. He notes that he has been struck by how other black academics were supportive. He states further:

I realized that the person who recruited me to the university was responsible for many other black academics joining the academy. I discovered that he shielded many of us from experiences that might otherwise have made this career untenable (Canham 2019:114).

This indicates how bodies of particular identities are marginalized. This continues even when others have made attempts to effect transformation for professional development and create an egalitarian society in South Africa.

Despite the support, we found ourselves conflicted, torn between our stake in the academic project and where we felt we belong. As a result, the academic space, which we entered with enthusiasm and passion, left us feeling like impostors, and the othering has made us feel frustrated and inadequate. It was in our conversations with other ECAs that we realized we had similar experiences and challenges. This propelled us to find ways to regain our power and confidence, and give back a sense of meaning and purpose to our work. Organically, a critical friendship was forged and, through continuous reflection, resulted in a collaborative and supportive, yet challenging relationship amongst us as professionals (Swaffield 2007). As we engaged with one another, owned our experiences, and reflected on them, we were able to identify the practices described above, recognize the impact they were having on our personal and professional growth, and found ways 
to mitigate them. Challenges ensued because we also had to look at our own biases and our part in the charade. We had to be self-reflexive, accept constructive criticism from one another and embrace multiple perspectives for growth to be achieved. This has been an ongoing process of learning that otherwise would not have been possible in the dominant space (Fletcher, Ní Chróinín \& O’Sullivan 2016). The friendship itself became educational as it taught integrity, accountability and discipline (LaBoskey 2004).

Unintentionally, we were and are involved in identity work where we co-construct our professional identities against the grain of the social identity that has been ascribed to us (Watson 2009). Through this work, we can now dis-identify from the work-imposed identities, influenced by the outer social identities, that view ECAs as deficient and incapable (Ybema et al. 2009). Instead, we have transitioned to an identity where we see ourselves as having agency and the ability to charter our own path. These are characteristics that we entered the academy with and that are consistent with and true to our 'authentic' selves (Costas \& Fleming 2009). This authentic self is constantly gaining, shedding the parts of who we were that no longer serve who we are becoming.

We write this article from our new positioning (the authentic self). We have reflected on our experiences and deduce that some of the practices in the dominant space are barriers to the realization of social cohesion. This deduction is based on the premise that social cohesion is characterized by group structures that foster a sense of belonging; non-exclusion, and a trustful and respectful relationship among its members (OECD 2011), characteristics that we seldom experienced. Because the environment in the dominant space was unfavourable and the norms and values were not consistent with our own, we could not find belonging (Fonseca et al. 2019).

This is extremely troubling, because one of the intended social benefits of HEIs is to enable the construction of a more socially cohesive society (Moiseyenko 2005). As academics, we first must attain this social cohesiveness if we are to impart it to those we teach. Our positioning as teacher educators places us at the fulcrums of change, where the teachers we produce must have the necessary understandings and behaviour profiles consistent with social cohesion, so that they too may be able to impart this to the learners they will teach. Teachers are at the centre of reform and its workforce (Connell 2011), suggesting that social cohesion at teacher education institutions is more significant. 


\section{Intersectionality Theory}

We adopted a feminist framework - intersectionality theory - as set out by Collins and Bilge (2016), Crenshaw (1991) and May (2015) to theorize ways in which social cohesion enables us as ECAs to redefine our identities at a teacher education institution. We are redefining our academic identity, rescuing it from negative views and attitudes projected onto us and ourselves. We can no longer allow ourselves to be affected by the negativity we encounter in the dominant space. We have a responsibility towards developing a thick skin and changing our views and perceptions of self as incapable. We have a responsibility to rescue ourselves. Undertaking the task of redefining our identities requires that we interrogate distinct types of social and professional identities, because who we are or become is shaped by multiple factors that we can learn from their convergence (Collins \& Bilge 2016; González \& Collins 2019). Intersectionality theory is therefore helpful in understanding complexities, experiences and inequalities that result from our intersecting identities (Collins \& Bilge 2016). Intersectionality is not only a set of ideas; instead, the framework's ideas 'have consequences to the social world' (Collins 2019:2). We explore the intersection of age, gender, sexuality, sex, race, ethnicity, and professional identities. In addition to these, we explore the intersection of forms of power and structural systems (May 2015), within a teacher education institution. Through the theory, we demonstrate how our critical friendship is aiding us to transcend the 'othering'/marginalization that exists in various parts of the institution, despite the findings of the 2008 Soudien Report on HEIs. We also show that our intersectional experiences help us to create a socially cohesive environment - building from our comprehensive backgrounds and histories. We build bottom-up in an alternative space where we engage as critical friends who are teacher educators and continuously ensure that discrimination does not thrive. As the Soudien report notes, discrimination and an environment with no sense of belonging have a negative impact on social cohesion (Department of Education 2008). Therefore, a feminist framework that focuses on identities is suitable.

\section{Working with Poetic Inquiry}

Our research for this study was guided by self-study methodology, using the arts-based poetic inquiry method. Poetic inquiry is a method of presenting data creatively while representing our lived experiences. Owton (2017:9) 
explains poetic inquiry as a 'methodological approach that seeks to reveal and communicate multiple truths via intuitive contemplation and creative expression'. Our choice to explore the arts-based methods was because we wanted a creative process to present our data artistically while retaining the emotive nuance within our narratives in ways that did not lose meaning. Guided by the characteristics of self-study, we immersed ourselves in the process, situating ourselves as the premise of this research, to generate new knowledge to aid our learning about our professional practice (LaBoskey 2004; Samaras 2011), so we can find solutions to improve our work (Hernández-Saca, Martin \& Meacham 2020).

We used poetic inquiry inspired by the various works of Faulkner (2016; 2019), Butler-Kisber (2005), Pithouse-Morgan et al. (2014), and Pithouse-Morgan and Samaras (2019). Faulkner and Butler-Kisber, in their writing about poetic inquiry, share useful steps through which researchers can illuminate their data using poetry. We were keen to explore the development of our professional identities and the aura of our professional space. In essence, through this process, we allowed our 'hearts to lead our minds rather than the reverse' (Butler-Kisber 2005:108). We sought to elicit creative and diverse ways of seeing and understanding the phenomenon (ibid.). Through poetic inquiry, we believed we would capture the nuances of our experiences in a more productive way than the conventional methods (Owton 2017). We framed our thinking around the approach of found poetry. Butler-Kisber (2018:97) defines found poetry as 'the rearrangement of words, phrases, and sometimes whole passages that are taken from other sources and framed as poetry by changes in spacing and lines (and consequently meaning), or by altering the text by additions or deletions'.

In conducting this research, it became vital for us to intermittently pause and reflect through conversation or writing (which we collate to produce for academic research) on our engagements, the environment we are creating, and the identities created through the process of professional collaboration. Through found poetry, we sought to move from a linear way of thinking and seeing to a more embodied text that represents our feelings and thoughts in a poetic form (Butler-Kisber 2005). Self-study and its practices allowed us the freedom to explore within our practice and ourselves, using multifaceted, innovative methods (Samaras 2011). Many of the methods we have been introduced to through self-study were not part of the conventional methods we were exposed to during our junior degrees and 
even our master's research thesis. Though a challenging activity, our academic writing has been and continues to be layered with exciting conversations, giving us intellectual climactic releases, that further ignite and deepen the passion of being teacher-educators and researchers.

\subsection{How We Went About It}

To begin our methodological process, we took insights and inspiration from Pithouse-Morgan and Samaras (2019). Drawing from their poetic bricolage process, we transcribed the virtual conversations we had (see example, Figure 1).

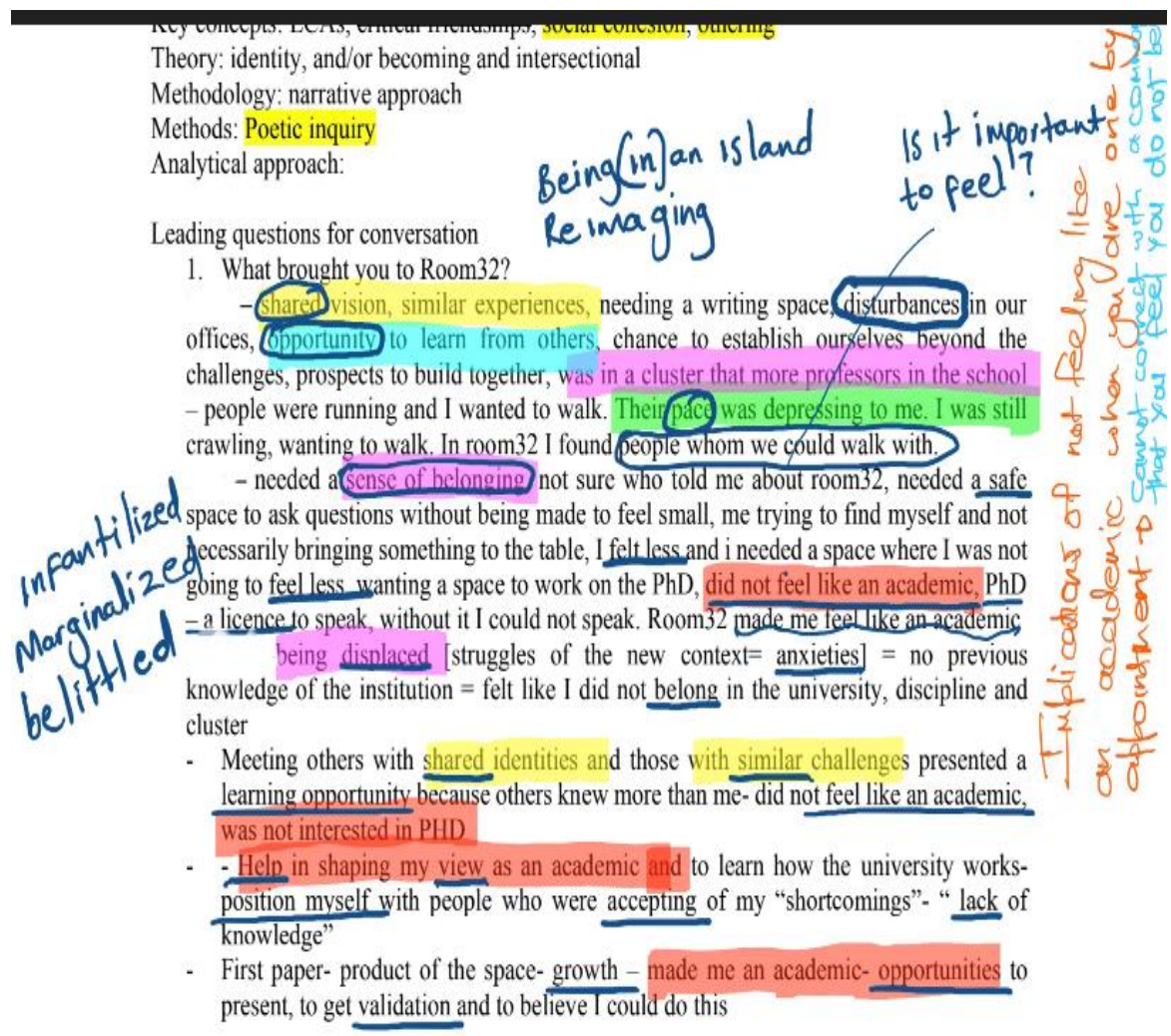

Figure 2: Excerpt from our transcriptions 
These conversations were prompted by the questions we had devised, relative to our broader process of exploring our ways of establishing social cohesion as we were preparing to contribute to this special issue.

A common method of poetic transcription entails researchers highlighting participants' exact words and language from interview transcripts, cutting and pasting the essential elements to reveal the essence of a participant's lived experience (Faulkner 2019:84).

In this overview of the methodological process, we sought to showcase how we moved from different parts of the text that involve conversations, feelings, sensations, and thoughts (Butler-Kisber 2018). In creating our found poem, we were encouraged by the following words, 'There is no template or prescribed approach for creating found poetry' (Butler-Kisber 2018:100).

We have shared and transcribed, using Microsoft (MS) Teams. From the assembly of responses, we reread, highlighted and underlined words that we felt resonated with or captured our thoughts and feelings. We then searched within those words for synonyms or relative similarities. One of the crucial procedures to maintain when working with poetic inquiry is to continuously read the data, to gain familiarity and find salient words that appeal to the researcher (Owton 2017).

Using OneNote, we opened a shared notebook where we took the highlighted words from MS Teams and began separating the words into groups, according to the relationship we felt they had with one another. We determined the relationship of the words based on our experiences' trajectory (how we remembered our narratives, our shared or similar experiences, how we were evolving and according to the words' synonymity). The finished product of this activity was the grouping of the words according to their relationship.

Grouping the words in this manner, we then discussed the words in each group again. Having looked at each group, we collectively discussed our thoughts on what was emerging from the grouped words. We further produced one word or a term that encapsulated each group and our experiences deepening this activity and our conversations. We thought these words would 'breathe life into the poem' (Butler-Kisber 2018: 100).

Having produced the word and term for each group of words, we 
began another process of highlighting words with these groups, words that we believed associated with our way of social cohesion among one another.

Slave, being given leftovers, given work that did not matter, denied opportunities, silenced, keeping my head down, being defined to be someone I am not, locked myself inside; being their timber; knighted; The crumbs

Similar experiences, shared vision, people whom we could walk with, similar challenges, shared identities, combined strength, collective, collaborations, nurture each other, harness our skills, reimaging, refining ideas, safe space, alternative, embracing diversity, walk with a similar pace, accepting; unorthodox; different lens;

Cultivate, help; opportunity to learn, sense of belonging, trust and respect, made me feel like an academic, building each other, see my capabilities, identify my strengths, we make each other, help in shaping my view, positioning, position myself, growth; recognition; worth, ideas value, validation; I am now able, share my ideas without feeling small, freely; find my voice; less afraid; give and get constructive feedback; heightens potential; lens of possibilities; being seen as an academic; helped me to see myself as an academic; practice without the license $(\mathrm{PhD})$; confidence; academic organisms; immersion, being an equal; tolerance; rescue my confidence; shedding; the island

Speak out/up; be heard; disagree; call out; assertion; challenging our biases; transform; avoid corridor talks; negotiate with self; agency; transgressing from the norm; redefining myself through my lens; building a stronger community; in my view; better mental health; personal and professional growth; shared vision and goals; autonomy

Figure 3: An example of how we arranged the words

In our discussions, we understood that these words also captured how we survived the forms of marginalization we encountered in the dominant space, and what we are creating for ourselves in the alternative space.

\section{Trustworthiness}

The reiterative methodological process of engaging with one another and the transcripts was one way we enhanced trustworthiness. This we drew from Mishler (1990), who argues that ongoing discourse among researchers is a means through which scientific knowledge is socially constructed while 
concurrently interrogating the very knowledge under construction. Glesne (1997) illustrates this in her work by including excerpts from her transcript, showing evidence of highlighted words that later were used in her poem.

\section{Echoes from the Island}

Infantilized, silenced,

In silos, incapable?

(in, under, down, out)

Being displaced. Disempowered?

Intentional?

Nonetheless, TAKE IT!

Accept the crumbs from the departmental meetings.

Vent through corridor talks

Or lock office doors,

"keep your head down."

Remember... you are the initiate.

Alternatively...

Finding possibility...

Encouraging a community of practice

Nurturing and safe;

Tolerant and accepting;

Of self of us ...

To practice without license, to collaborate,

To negotiate with lenses and positionings of dominance.

It is unorthodox, unprescribed

Yet enabling;

Challenges biases - yet embraces diversity.

Redefining, reimaging.

OUR island.

To gain confidence - to speak up,

And transgress from complicit behaviours of marginalisation.

Respecting OUR views and trusting OUR vision.

Strength through OUR community; harnessing OUR professional growth.

We are taking the Metro rail together.

\section{Figure 4: Our poem}


Such transparency is encouraged in self-study work and builds on the authenticity and credibility of the work presented (Butler-Kisber 2018). Similarly, Pithouse-Morgan and Samaras (2019), in their poetic bricolage process, enhance their trustworthiness by including their word clouds and various short poems from the multiple steps they took to refine their data and represent their final piece.

\section{Unpacking Echoes from the Island}

Our poem serves as an ongoing engagement with ourselves and an opportunity to share our experiences as ECAs with the academic community. This method has also given us a chance to integrate the tool of emotionality (Owton 2017), which may assist to deepen the reader's understanding. Below are the three themes that emerged when discussing the poem with one another.

\subsection{Seeing Ourselves and Being Seen}

When we entered academia, we came in with diverse backgrounds, histories, and a variety of identities. We assumed that our common identities would be an asset given that the transformation agenda was and is in the rhetoric. Nevertheless, we did not see ourselves as transformation projects or what Khoza-Shangase (2019) refers to as transformation candidates. In the academy, there is the reality of the ageing professoriate, and ECAs are needed for the continuation of knowledge generation. Therefore, we were ready to undergo inductions, interact with the university community, and immerse ourselves in learning and unlearning; perhaps we were prepared to become the timber ${ }^{1}$. We saw ourselves on an upward trajectory in our personal and professional development.

Starting the journey of becoming academics (becoming ourselves in academia) was crowded and interrupted by imposed definitions of who and where we should be. As noted earlier, before our entry, we had imagined higher education as a space where ideas and rigorous debates take place,

${ }^{1}$ Timber: a term used within the university that identifies the students who have graduated from the University and have re-joined as academic or professional staff. 
where marginalization has no place. This is not suggesting that these engagements do not take place - they do, but they are hierarchized and often accompanied by an intention to marginalize, pushout and displace ECAs. Our experiences as ECAs are not dissimilar to those at other institutions, particularly considering the unequal history in South Africa. Those who are at a research-intensive institution constantly face the pressure to 'publish or perish'. Put simply, 'publish or perish', is the dominant lens through which the first form of othering occurs. The forms of marginalization intentionally or unintentionally enacted upon us heightened the feeling of inferiority and the impostor syndrome within us individually, changing how we had seen ourselves (Gardner \& Blackstone 2013; Karreman \& Alvesson 2001). These feelings impacted our becoming, deepened personal perceptions of inferiority, resulting in challenging socialisation relations. Consequently, we had been silenced, but we had also silenced ourselves by adopting the expectations of when to speak and when not (Canham 2019).

Being displaced and subjected to forms of othering resulted in our being in a position of liminality (Beech 2011; Chreim 2002) is what Turner (1969) explains as being betwixt and between. This is what compelled us to retreat to Room32 for refuge and self-development (Ndlovu, Msiza \& Mbatha 2021). In the dominant space, we did not experience concerted efforts towards social cohesion; in most cases, we experienced belittlement based on age (Mbatha et al. 2020) and lack of experience. It appeared that the diversity of identities was not valued (Hernández-Saca et al. 2020). This was contrary to our expectations (Beech 2011) and, once we realized this, we sought an alternative space, Room32, where the work of self-development began. These happenings were also inconsistent with the characteristics needed to create social cohesion. Social cohesion is attained through collaboration and shared vision, where everyone commits to forging meaningful human relationships with university members (Heyneman et al. 2007; McAnulty \& Cuenca 2014). In our case, the identities that were imposed and internalized by us were impeding our struggle to become and our ability to work against. In their work detailing some of the challenges they experienced in advancing from early career to mid-career academics, Casey and Fletcher (2017) illustrate the complexities associated with aligning with their university and discipline prerogatives while having control over their research agendas. These scholars highlight the frustrations related to the norms they had to accept because they were tied to internal advancement. 
These scholars had to let go of the research agendas they preferred for those that could attract funding. In our case, we had to let go of who we were so we could fit in with the prevailing status quo. Our behaviours and ideas about who we are were starting to conform to the work-imposed identities (influenced by the outer social identities) that view ECAs as being deficient and incapable (Ybema et al. 2009).

Heads once held up, were now down. In the context of teaching and learning, different departments at the school facilitate workload allocation meetings at the beginning of each year. Senior staff members often select postgraduate modules such as master's and honours, while those who occupy a lower rank, particularly those who are new to the system, are expected to choose from a list of what nobody wants (leftovers). Doing things in this fashion has created an assumption that the leftovers are for ECAs. It has presented the process as a covert rite of passage, with ECAs being the initiates. In a socially cohesive environment, there should be an equitable sharing of workloads, ensuring not only equal quantity but also the opportunity for ECAs to co-teach the postgraduate modules, for developmental purposes. The left-over approach deepens an elitist behaviour in the academy and creates categories where ECAs are positioned at the lower end of the hierarchy.

\subsection{Our Rescue and Letting Go}

Considering the content of the previous theme, seeing ourselves and being seen, we did not want to reside in pain and become passive, marginalized teacher educators. Despite the negative experiences that were discussed in the previous theme, some of the intersectional experiences were helpful in enabling us to reflect on ourselves and the academy. We soon noted that we needed to engage in a deep reflexive exercise that would yield ideas about rescuing ourselves, letting go of the toxic norms, and eventually creating a socially cohesive environment. When we started the reflexive process, we considered some of the following things: we acknowledged the negativity that was projected on us and by us towards ourselves. For example, we departed from the premise of victimhood wherein we would wait passively for a senior academic to rescue us either through professional development or through offering/suggesting opportunities. We began to facilitate the process of creating social cohesion and a sense of belonging for ourselves 
(Canham 2019). This indicates that, in our rigorous reflexive engagements, our different identities intersected; being female or male, black, ethnicity, young, ECA in a research-intensive university, as did our socio-economic statuses mattered. Our experiences were rich and varied, but being an ECA, young and research unproductive (at the time), were experiences that we shared.

For us to begin the process of rescuing ourselves from belligerent domination and attitudes, we had numerous discussions about our experiences. These discussions were conducted in our alternative space, which we call Room32 (Ndlovu et al. 2021). In this space we were able to be vulnerable to each other because, herein, our lived experiences were validated (Hernández-Saca et al. 2020). This vulnerability became empowering, in line with Brown (2012:34), who expresses vulnerability as '... the birthplace of love, belonging, joy, courage, empathy, and creativity. It is the source of hope, empathy, accountability, and authenticity'. What had started out as a network, where we naturally came together to discuss experiences and frustrations and share good practice and ideas (Crawford 2011), was evolving into a critical friendship.

We started being intentional about what we were doing and how we were going to do it. This was so we would not fall into the trap of reproducing the very same environment from which we were rescuing ourselves. Berman (2020) cautions that one of the unchallenged assumptions about informal spaces (like our island) is that contestations and conflicts are scarce. Even amongst colleagues of the same level, practices of exclusion and marginalisation may be reproduced. We did not want that. We were in a safe space that was unprescribed, and we had an opportunity to prescribe it for ourselves. Together in Room32, as critical friends, we deliberately found ways to give power to our voices that we felt were previously silenced (Olan \& Edge 2018). Room32, having no prescribed norms of living together, allowed us to establish organizational practices that we saw fit and agreed to collectively. Through our critical friendship, we managed to create an atmosphere of belonging, tolerance, and trust. We were rescuing ourselves by constructing alternate ways of being that placed emphasis on the importance of relationships and rejected individualism and competition (Taylor \& Klein 2018).

Once again, we were engaged in identity work. We were able to acknowledge and identify our biases, reflect on them, and shed the parts that 
no longer served who we were becoming. We did this while simultaneously rescuing that which had been diminished within ourselves and was still relevant to our becoming. The intersectional framework and critical friendship made the reflexive process possible. We confronted the complexities brought by our varied identities and the experiences thereof. For example, in one of our conversations; Vusi (a male co-author) noted the following:

No doubt patriarchy is attractive to every man; we all benefit from it and my admission of this is one step towards change. I think being in Room32 assisted me to be conscious of the benefits. I constantly challenged myself from expecting the fellow Room32 dwellers to make tea, prepare food or clean up. So, it was not because I asked, they did all these out of their will, but I thought to establish a socially cohesive and egalitarian environment I needed to consistently challenge the gender norms that only benefitted me.

Our critical friendship that was established in our doctoral journeys of using self-reflexive methodologies created an atmosphere wherein we supported, encouraged, challenged each other, and maintained the purpose of practice in the academy and to an extent social life (Schuck \& Russell 2005). It empowered us to disrupt the taken-for-granted ways of being and doing and gave us the agency to explore new ways of what it meant to be a young, Black ECA in a research-intensive teacher educator institution (Brown \& Duguid 1991; Taylor \& Klein 2018). Our critical friendship is made up of positive elements such as respect, trust, support, and flexibility (Schuck \& Russell 2005), but we also have an epistemology of friendship that is intentional and pro-empowerment. Through it, we have a support mechanism that in turn sustains our resistance to institutional and systemic norms that attempt to marginalize us and hinder social cohesion (Taylor \& Klein 2018). Our critical friendship has therefore turned to be an intrinsic mode of self-critique, transformation, and resistance to marginalisation (Taylor \& Klein 2018).

\subsection{Transgressing and Reclaiming}

The dialogues and discussions we have mentioned have given us the impetus to engage in the identity work and to rescue ourselves and let go. This meant 
transgressing from the norm and its dictates. 'Home (the dominant space) was (is) the place where I was (am) being forced to conform to someone's image of who and what I should be (and behave). School (Room32) was (is) the place where I could (can) forget that self and, through ideas, reinvent myself' (Hooks 1994:3). We had to stay in Room32 more frequently, validate one another, forge a new understanding of being an academic that was influenced and modelled from the literature and cohesive cultures from those we saw as mentors on campus and in the broader academic community. We also had to be intentional in our profession; that is, do the work and block the noise.

It would not be proper to leave out the other practices that we have adopted to assist us in working and blocking the noise. They enhance and enable our strength in our community, and harness our professional growth as teacher educators. This is because we position ourselves as whole beings and our development must be about self and our professional ambitions and growth. Like Hooks (1994:16), we 'maintain the fidelity to the idea of the intellectual as someone who sought to be whole', placing emphasis on 'spiritual well-being, on care of the soul'.

We find similarity in our practices and behaviours with those of Taylor and Klein (2018), who have also used their friendship as a framework of support and a means of resistance against hegemonic practices that emphasize competition and individualism in the academy. When we write a paper, we value one another's contributions, but we also acknowledge the power of our combined intellectual capitals and insights. We take turns being the first author, rather than debating who led the paper or who did the most work. We have different personalities and strengths and draw on these to make the whole better than the individual parts, complementing one another instead of competing. For us, these practices and behaviours that are based on interdependence, mutuality and respect are a manifestation of the discussions we have. It is through our thoughts, words, and actions that we are transgressing because, within our context, models of such collaborative work amongst ECAs are rare, arguably even amongst senior academics.

\section{Moving Forward and Wrapping Up}

Though an uncomfortable experience, being othered has pushed us to reach greater depths within ourselves. Room 32 has given us an opportunity to be 
our authentic selves and be invested in professional growth while encourageing a community of practice among ourselves. In seeking a collegial space, we became intentional. We learned to express kindness, convey trust in one another and the space, take an interest in one another's doctoral studies and listen to one another. All these were supportive efforts among us, which highly contribute to our cohesiveness. We are learning to share and receive feedback from one another in a constructive manner and to be tolerant of our differences. Such practices have resulted in deeper trust and respect for one another as we have allowed ourselves to learn from one another's views and strengths.

Professionally we are teacher educators who also do research in education; we are cognisant of the implications that our identities have, and at this point, we would like to address two. Firstly, we are in a teacher education institution wherein we graduate future teachers who will impact hundreds of thousands of learners in the country and abroad. We believe that if we can create social cohesion in Room 32 and encourage it in the broader institution amongst staff members, it is our utmost responsibility to collectively encourage it amongst students as well. This is more significant because of the never ending racial, gender and sexual intolerance that exists in South Africa. As Connell (2011) notes, teachers (teacher educators in our case) are agents of reform, we carry the work of transformation, and even post the Soudien report, South Africa still yearns for social cohesion. We therefore align with Hernández-Saca et al.'s (2020:30) argument on diversity and reform.

I did not want my students to teach at schools with diverse populations, and not understand that implicit bias, stereotypes and stereotype threat can do great harm to students. It was my charge to prepare students to work in diverse environments.

Secondly, we see ourselves as the future of academia, future leaders in our respective fields and managerial positions. We may not yet be senior academics; however, we believe in each other and are on the Metrorail ${ }^{2}$

${ }^{2}$ Metrorail metaphorical meaning: Compared to others, our pace appears to be slow, hence we are describing it as the Metrorail as opposed to the Gautrain which is a high-speed train. 
together, taking an alternative path to the professorship. This path may seem slower and a bit longer to others, but at least we are rescuing ourselves from exploitation, from taking leftovers and feeling like impostors. We are learning to be confident in our abilities, assertive in our academic pursuit and resilient in our challenges. Our initiatives in Room32, specifically those who fostered social cohesion, prepare us to contribute to a better HEI that South Africa needs. So, in the words of Chris Brown (2009) '... we can still touch the sky, if we crawl till, we can walk again, then we'll run until we strong enough to jump, then we'll fly until there is no wind, so let's crawl ...'.

\section{Acknowledgements}

We would like to acknowledge the assistance of Dr. Bridget Campbell for reading our Poem and providing feedback.

\section{References}

Berman, N. 2020. A Critical Examination of Informal Learning Spaces. Higher Education Research \& Development 39,1: 127 - 140. https://doi.org/10.1080/07294360.2019.1670147

Beauvais, C. \& J. Jenson 2002. Social Cohesion: Updating the State of the Research. Volume 62. Ottawa: CPRN.

Beech, N. 2011. Liminality and the Practices of Identity Reconstruction. Human Relations 64,2: 285 - 302. https://doi.org/10.1177/0018726710371235

Berkman, L.F. \& I. Kawachi 2000. Social Cohesion, Social Capital, and Health. In Berkman, L.F. \& I. Kawachi (eds): Social Epidemiology. New York: Oxford University Press.

Brown, B. 2012. Daring Greatly: How the Courage to be Vulnerable Transforms the Way We Live, Love, Parent, and Lead. New York: Avery.

Brown, C. 2009. Crawl. New York: Jive Records.

Brown, J.S. \& P. Duguid 1991. Organizational Learning and Communitiesof-Practice: Toward a Unified View of Working, Learning, and Innovation. Organization Science 2,1: 40 - 57.

https://doi.org/10.1287/orsc. 2.1 .40

Belluigi, D.Z. \& G. Thondhlana 2018. Insights into the Lived Experiences 
Nosipho Mbatha, Vusi Msiza \& Nokukhanya Ndlovu

of So-Called Future Leaders of Historically White Institutional Evaluation Processes. Paper presented at $2^{\text {nd }}$ Annual International Symposium, Athens, Greece. Available at:

https://pureadmin.qub.ac.uk/ws/ portalfiles/portal/

155671883/Belluigi Thondhlana 2018Insights Atiner.pdf

(Accessed on 12 January 2021.)

Butler-Kisber, L. 2005. Inquiry through Poetry: The Genesis of Self-study.

In Mitchell, C., S. Weber \& K. O'Reilly-Scanlon (eds): Just Who Do

We Think We Are? Methodologies for Self-study in Education. New

York, NY: Routledge.

Butler-Kisber, L. 2018. Qualitative Inquiry: Thematic, Narrative and Arts-

Based Perspectives. Thousand Oaks, CA: Sage Publications.

https://doi.org/10.4135/9781526417978

Canham, H. 2019. The Polemic Body. In Khunou, G., E.D. Phaswana, K.

Khoza-Shangase \& H. Canham (eds): Black Academic Voices: The

South African Experience. Cape Town: HSRC Press.

Capshaw, N.C. 2005. The Social Cohesion Role of the Public Sector.

Peabody Journal of Education 80,4: 53 - 77.

https://doi.org/10.1207/S15327930pje8004 5

Casey, A. \& T. Fletcher 2017. Paying the Piper: The Costs and Consequences of Academic Advancement. Sport, Education and Society 22,1: 105 121. https://doi.org/10.1080/13573322.2016.1168795

Chreim, S. 2002. Reducing Dissonance: Closing the Gap between Projected and Attributed Identity. In Moingeon, B. \& G. Soenen (eds): Corporate and Organizational Identities. Abingdon: Routledge.

https://doi.org/10.4324/9780203361726.pt2

Cisco, J. 2019. Exploring the Connection between Impostor Phenomenon and Postgraduate Students Feeling Academically Unprepared. Higher Education Research \& Development 39,2: 200 - 214.

https://doi.org/10.1080/07294360.2019.1676198

Collins, P.H. 2019. Intersectionality as Critical Social Theory. Durham, NC:

Duke University Press. https://doi.org/10.1515/9781478007098

Collins, P.H. \& S. Bilge 2016. Intersectionality. Cambridge: Polity Press.

Connell, R. 2011. Confronting Equality: Gender, Knowledge, and Global Change. Cambridge, UK: Polity Press.

Costas, J. \& P. Fleming 2009. Beyond Dis-identification: A Discursive Approach to Self-alienation in Contemporary Organizations. Human 
Relations 62, 3: 353 - 378. https://doi.org/10.1177/0018726708101041 Crawford, E.R. 2011. Team Network Multiplexity, Synergy, and Performance, unpublished $\mathrm{PhD}$ thesis, University of Florida, FL USA. Crenshaw, K. 1991. Mapping the Margins: Intersectionality, Identity Politics, and Violence against Women of Color. Stanford Law Review 43, 6: 1241 - 1299. https://doi.org/10.2307/1229039

Department of Education [DoE] 2008. Report of the Ministerial Committee on Transformation and Social Cohesion and the Elimination of

Discrimination in Public Higher Education Institutions. Pretoria: Government Printers.

Department of Higher Education and Training [DHET] 2015. Foreword by Dr B.E. Nzimande. In Department of Higher Education and Training. Available at: https://www.ssauf.dhet. gov.za/home.html (Accessed on 04 January 2021.)

Durkheim, E. 1897. Le Suicide: Étude de Sociologie. New York, NY: F. Alcan.

Eley, A., J. Wellington, S. Pitts \& C. Biggs 2012. Becoming a Successful Early Career Researcher. New York: Routledge.

https://doi.org/10.4324/9780203113073

Faulkner, S.L. 2016. Poetry as Method: Reporting Research through Verse.

New York: Routledge. https://doi.org/10.4324/9781315422411

Faulkner, S.L. 2019. Poetic Inquiry: Craft, Method, and Practice. New York: Routledge. https://doi.org/10.4324/9781351044233

Fletcher, T., D. Ní Chróinín \& M. O’Sullivan 2016. A Layered Approach to Critical Friendship as a Means to Support Pedagogical Innovation in Pre-Service Teacher Education. Studying Teacher Education 12,3: 302 - 319. https://doi.org/10.1080/17425964.2016.1228049

Fonseca, X., S. Lukosch \& F. Brazier 2019. Social Cohesion Revisited: A New Definition and How to Characterize It. Innovation: The European Journal of Social Science Research 32,2: 231 - 253.

https://doi.org/10.1080/13511610.2018.1497480

Gardner, S.K. \& A. Blackstone 2013. 'Putting in Your Time': Faculty Experiences in the Process of Promotion to Professor. Innovative Higher Education 38,5: 411 - 425.

https://doi.org/10.1007/s10755-012-9252-x

Glesne, C. 1997. That Rare Feeling: Re-presenting Research through Poetic Transcription. Qualitative Enquiry 3, 2: 202 - 221. 
https://doi.org/10.1177/107780049700300204

González, A.O. \& P.H. Collins 2019. Interview with Patricia Hill Collins on

Critical Thinking, Intersectionality and Educational: Key Objectives for

Critical Articulation on Inclusive Education. Journal for Critical Education Policy Studies (JCEPS) 172: 151 - 170.

https://doi.org/10.31231/osf.io/9sf2u

Hernández-Saca, D.I., J. Martin \& S. Meacham 2020. The Hidden Elephant

Is Oppression: Shaming, Mobbing, and Institutional Betrayals within the Academy - Finding Strength in Collaborative Self-Study. Studying Teacher Education 16,1: 26 - 47.

https://doi.org/10.1080/17425964.2020.1727430

Heyneman, S.P., R. Kraince, N. Lesko \& M. Bastedo 2007. Higher

Education and Social Cohesion: A Comparative Perspective. In Altbach, P.G. \& P.M. Peterson (eds): Higher Education in the New Century: Global Challenges and Innovative Ideas. Rotterdam: Sense Publishers.

Hooks, B. 1994. Teaching to Transgress: Education as the Practice of Freedom. New York: Routledge.

https://doi.org/10.3366/para.1994.17.3.270

Karreman, D. \& M. Alvesson 2001. Making Newsmakers: Conversational Identity at Work. Organization Studies 22,1: 59 - 89.

https://doi.org/10.1177/017084060102200103

Khoza-Shangase, K. 2019. Intellectual and Emotional Toxicity: Where a Cure Does Not Appear to be Imminent. In Khunou, G., E.D. Phaswana, K. Khoza-Shangase \& H. Canham (eds): Black Academic Voices: The South African Experience Cape Town: HSRC Press.

Khunou, G., E.D. Phaswana, K. Khoza-Shangase \& H. Canham (eds.). 2019.

Black Academic Voices: The South African Experience. Cape Town: HSRC Press.

LaBoskey, V.K. 2004. The Methodology of Self-Study and its Theoretical Underpinnings. In Loughran, J.J., M.L. Hamilton, V.K. LaBoskey \& T. Russell (eds): International Handbook of Self-Study of Teaching and Teacher Education Practices Dordrecht: Springer.

https://doi.org/10.1007/978-1-4020-6545-3 21

Mahabeer, P., N. Nzimande \& M. Shoba 2018. Academics of Colour: Experiences of Emerging Black Women Academics in Curriculum Studies at a University in South Africa. Agenda 32,2: 28 - 42. 
https://doi.org/10.1080/10130950.2018.1460139

May, V.M. 2015. Pursuing Intersectionality, Unsettling Dominant Imaginaries. New York, NY: Routledge.

https://doi.org/10.4324/9780203141991

Mbatha, N., V. Msiza, N. Ndlovu \& T. Zondi 2020. The Academentia of ECAs: Navigating Academic Terrain through Critical Friendships as a Life Jacket. Educational Research for Social Change 9: 31 - 44. https://dx.doi.org/10.17159/2221-070/2020/v9i2a3

McAnulty, J. \& A. Cuenca 2014. Embracing Institutional Authority: The Emerging Identity of a Novice Teacher Educator. Studying Teacher Education 10,1: 36 - 52.

https://doi.org/10.1080/17425964.2013.862493

Moiseyenko, O. 2005. Education and Social Cohesion: Higher Education. Peabody Journal of Education 80,4: 89 - 104.

https://doi.org/10.1207/S15327930pje8004_7

Mishler, E.G. 990. Validation Inquiry-guided Research: The Role of Exemplars in Narrative Studies. Harvard Educational Review 60,4: 415 - 442. https://doi.org/10.17763/haer.60.4.n4405243p6635752

Moodley, K., A. James \& M. Stears 2015. Reflections of a Novice Academic Writer. Educational Research for Social Change 4,2: 75 - 88.

Naicker, L. 2013. The Journey of South African Women Academics with a Particular Focus on Women Academics in Theological Education. Studia Historiae Ecclesiasticae 39: 325 - 331.

Ndlovu, N., V., Msiza \& N. Mbatha 2021. Room32: An Academic Oasis for our Informal Conversations to Enhance Teaching and Learning, International Journal for Academic Development 1 - 5 .

https://doi.org/10.1080/1360144X.2021.1954525

Novy, A., D.C. Swiatek \& F. Moulaert 2012. Social Cohesion: A Conceptual and Political Elucidation. Urban Studies 49,9: 1873 - 1889.

https://doi.org/10.1177/0042098012444878

Olan, E.L. \& C. Edge 2018. Critical Friends as Co-authors: Pushing Boundaries and Crossing Borders Together. In Garbett, D. \& A. Ovens (eds): Pushing Boundaries and Crossing Borders: Self-Study as a Means for Researching Pedagogy. Herstmonceux, UK: Self-Study of Teacher Education Practices (S-STEP).

Organisation for Economic Co-operation and Development [OECD] 2011. Perspectives of Global Development 2012: Social Cohesion in a 
Nosipho Mbatha, Vusi Msiza \& Nokukhanya Ndlovu

Shifting World. https://read.oecd-

ilibrary.org/development/perspectives-on-global-development-

012 persp glob dev-2012-en\#page1 (Accessed on 5 January 2020.)

Owton, H. 2017. Doing Poetic Inquiry. Switzerland: Springer.

https://doi.org/10.1007/978-3-319-64577-3

Phaswana, E.D. 2019. The Limits of Being and Knowledge in the Academy.

In Khunou, G., E.D. Phaswana, K. Khoza-Shangase \& H. Canham

(eds.): Black Academic Voices: The South African Experience. Pretoria: HSRC Press.

Pinar, W.F. 2004. What is Curriculum Theory? Mahwah, NJ: Lawrence Erlbaum Associates.

Pithouse-Morgan, K., I. Naicker, V. Chikoko, D. Pillay, P. Morojele \& T. Hlao 2014. Entering an Ambiguous Space: Evoking Polyvocality in Education Research Through Collective Poetic Inquiry. Perspectives in Education 32,4: 149 - 170.

Pithouse-Morgan, K. \& A.P. Samaras 2019. Polyvocal Play: A Poetic Bricolage of the Why of Our Transdisciplinary Self-Study Research. Studying Teacher Education 15,1: 4 - 18.

https://doi.org/10.1080/17425964.2018.1541285

Samaras, A.P. 2010. Self-study Teacher Research: Improving Your Practice Through Collaborative Inquiry. Thousand Oaks, CA: Sage.

Schuck, S. \& T. Russell 2005. Self-study, Critical Friendship, and the Complexities of Teacher Education. Studying Teacher Education 1,2: 107 - 121. https://doi.org/10.1080/17425960500288291

Swaffield, S. 2007. Light Touch Critical Friendship. Improving Schools 10,3: $205-219$.

https://doi.org/10.1177/1365480207077845

Taylor, M. \& E.J. Klein 2018. Tending to Ourselves, Tending to Each Other: Nurturing Feminist Friendships to Manage Academic Lives. In Lemon, N. \& S. McDonough (eds.): Mindfulness in the Academy: Practices and Perspectives from Scholars. Singapore: Springer. https://doi.org/10.1007/978-981-13-2143-6 7

PMCid:PMC6482605

Turner, V. 1969. Liminality and Communitas. The Ritual Process: Structure and Anti-structure 94,113: 125 - 30.

https://doi.org/10.4324/9781315134666-3

PMCid:PMC5390449 
Watson, T.J. 2009. Narrative, Life Story and Manager Identity. Human Relations 63,3: 425 - 452.

https://doi.org/10.1177/0018726708101044

Wright, C., S. Thompson \& Y. Channer 2007. Out of Place: Black Women Academics in British Universities. Women's History Review 16,2: 145 - 162. https://doi.org/10.1080/09612020601048704

Ybema, S., T. Keenoy, C. Oswick, A. Beverungen, N. Ellis \& I. Sabelis 2009. Articulating Identities. Human Relations 63,3: 299 - 322. https://doi.org/10.1177/0018726708101904

Nosipho Mbatha Lecturer Creative Arts University of KwaZulu-Natal Durban Mbathan5@ukzn.ac.za

Vusi Msiza Lecturer Early Childhood Education University of KwaZulu-Natal

Durban msizav@ukzn.ac.za

Ms. Nokukhanya Ndlovu Lecturer Educational Leadership, Management and Policy University of KwaZulu-Natal Pietermaritzburg Satimburwan@ukzn.ac.za 